\title{
Síla stisku ruky u sportovních gymnastek
}

\author{
Martin Čuta ${ }^{1}$ - Anna Vážná \\ 1 Ústav antropologie, Př́rodovědecká fakulta, Masarykova univerzita, Brno, Česká republika \\ 2 Katedra antropologie a genetiky člověka, Přírodovědecká fakulta, Univerzita Karlova, Praha, Česká republika
}

Do redakce doručeno 3. března 2021; k publikaci přijato 1. prosince 2021

\section{HAND GRIP STRENGTH IN YOUTH FEMALE ARTISTIC GYMNASTS}

\begin{abstract}
In athletes who compete in artistic gymnastics, the requirements of the discipline result in a specific body build type. Among other characteristics they must have strong upper limbs. This article focuses on hand grip strength, a characteristic considered to be a suitable indicator of overall body strength. The parameters measured also included body height and weight, and forearm circumference. The study sample consisted of 42 youth female artistic gymnasts and a control group consisting of 68 students of the same age categories. The data analysed included information on 40 athletes and 52 students. Differences in hand grip strength were observed between the athletes and the control group in the first and second age categories, and differences in body height were observed only in the third age category. At younger ages, gymnasts did not differ from the control group in terms of body height, but higher upper limb strength was observed.
\end{abstract}

KEY WORDS Artistic gymnastics; gymnasts; hand grip strength; dynamometry; body height

\begin{abstract}
ABSTRAKT Tělesný habitus sportovních gymnastek je dán náročností tohoto sportu. Sportovní gymnastky musí krom dalších charakteristik disponovat i silou v horních končetinách. V rámci naší práce jsme se soustředili na sílu stisku ruky, který je vhodným ukazatelem celkového stavu silových schopností svalstva. Tento ukazatel byl doplněn o měření tělesné výšky, hmotnosti a obvodů předloktí. V rámci výzkumu byly celkem změřeny tyto charakteristiky u 42 sportovních gymnastek, které byly porovnány dle věkového rozdělení s hodnotami 68 studentek. Vyhodnocení proběhlo u 40 gymnastek a 52 studentek. Rozdíl v síle stisku ruky gymnastek a kontrolní skupiny byl nalezen v př́ípadě první a druhé věkové kategorie. Rozdíl v tělesné výšce byl nalezen pouze ve třetí věkové kategorii. Bylo též zjišsěno, že se tělesnou výškou v nižším věku sportovní gymnastky neodlišují, ale byla u nich pozorována zvýšená svalová síla horních končetin.
\end{abstract}

KLÍČOVÁ SLOVA Sportovní gymnastika; gymnastky; síla stisku ruky; dynamometrie; tělesná výška

\section{ÚVOD}

Síla stisku ruky, měřená pomocí dynamometrů/siloměrů, patři k významným metodám hodnocení fyzické kondice. Jedná se o jednoduché vyšetření, které lze, při zachování určitých zásad a standardizaci postupu, provést i mimo laboratorní podmínky. V našem prŕpadě jsme použili elektromechanický dynamometr Chatillon DFS II (Ametek 2015), měřící u svalových skupin izometrickou sílu. $\mathrm{V}$ našem případě byla tato metodika využita pro zhodnocení silových schopností sportovních gymnastek od 7 do 13 let věku vzhledem ke stejné věkové skupině v populaci. Sportovní gymnastika je náročným sportem, který zapojuje do pohybu celé tělo (Skopová - Zítko 2013). Na základě této znalosti dále předpokládáme, že intenzivní př́íprava ve sportovní gymnastice má vliv na sílu stisku ruky. Tento předpoklad je založen na objemu a intenzitě náplně sportovní př́pravy i samotného tréninku sportovní gymnastiky (Krištofič 2006; 2009). Pro sportovní gymnastiku je typická sportovní příprava v útlém věku. Děti se učí základní dovednosti a součástí je i vhodně připravený silový trénink, který pomáhá připravit se na cviky, které se bude učit dívka v budoucnu, ale také podporuje stabilitu kloubních spojení (Dovalil - Choutka 2002a; 2002b). Trénink tedy kromě dalších průprav obsahuje všestrannou silovou př́pravu, jak v pojetí klasického posilování, tak v modifikacích gymnastických prvků, které vyžadují specifické zapojení svalových skupin (Dovalil - Choutka 2002a). Zapojení horních končetin ve sportovní gymnastice nacházíme nejen při cvičení na hraz- 
dě či bradlech o nestejné žerdi, ale i při odrazech na přeskoku nebo $\mathrm{v}$ polohách ve stoji na rukou, a to jak na prostných, tak na kladině (Dovalil - Choutka 2002a; Rogol - Clarc - Roemmich 2000; Skopová - Zítko 2013). Horní končetiny jsou tedy intenzivně namáhány, a proto u nich můžeme testovat za pomoci dynamometrie hodnoty síly stisku a při porovnání s kontrolní skupinou hledat možné odchylky od běžné populace. Kromě silové náročnosti je sportovní gymnastika i technicky náročným sportem. Právě kvůli technické náročnosti prvků přináší nižší tělesná výška určité výhody (Hedbávný - Cacek; Svobodová 2014; Riegerová - Valenta - Ulbrichová 2006). I tento faktor jsme společně s tělesnou hmotností vzali $\mathrm{v}$ potaz při komparaci nasbíraných dat.

\section{CÍl PRÁCE}

Cílem práce bylo zejména zachytit, zda se sportovní gymnastky vymykají svou silou stisku ruky ze své věkové kategorie v porovnání s kontrolní skupinou. Dále pak bylo cílem porovnat i další parametry jako je tělesná výška, hmotnost a BMI. $\mathrm{V}$ rámci zhodnocení rozvoje svalstva předloktí byla hledána i souvislost mezi obvodem předloktí a silou stisku ruky.

\section{MATERIÁL A METODY}

Výzkumu se zúčastnily sportovní gymnastky a studentky, tvořící kontrolní skupinu. O spolupráci byli požádáni trenéři a trenérky gymnastických oddílů a ředitelé škol, kteří také zajištovali distribuci i následné shromáždění dotazníků s informovanými souhlasy. Podmínkou pro účast byl rodiči podepsaný informovaný souhlas a vyplněný dotazník. Kontrolní skupina byla vytvořena na základě početního rozložení ve věkových kategoriích sportovních gymnastek. Věkové kategorie vycházely ze stanov Rozpisu soutěže sportovní všestrannosti ČOS na cvičební rok 2017/2018, který je volně přístupný na adrese www.sokol.eu. Zvolili jsme tyto čtyři kategorie:
I. kategorie 7-9 let
II. kategorie $\quad 10-11$ let
III. kategorie 12-13 let
IV. kategorie $\quad 14-15$ let

Ke spolupráci svolily 3 gymnastické oddíly z Čech i Moravy. $\mathrm{V}$ návaznosti na počet naměřený gymnastek byly požádány o spolupráci dvě základní školy a gymnázium, aby se mohlo uskutečnit měření probandek kontrolní skupiny. Měření se účastnily studentky $\mathrm{z}$ tříd 1 . stupně a 6 . třídy na základních školách a studentky sekundy, tercie a kvarty gymnázia.

\section{Základní charakteristika souboru}

Studie se zúčastnilo 42 sportovních gymnastek a 68 studentek. Zastoupení dívek v jednotlivých kategoriích bylo následující. U sportovních gymnastek bylo naměřeno $\mathrm{v}$ I. kategorii 14 dí- vek, ve II. kategorii 21 dívek, ve III. kategorii 5 dívek a ve IV. kategorii 2 dívky. Ve skupině studentek bylo naměřeno v I. kategorii 22 dívek, v II. kategorii 15 dívek, ve III. kategorii 15 dívek a ve IV. kategorii 16 dívek. $Z$ důvodů nízkého počtu sportovních gymnastek ve IV. kategorii jsme se rozhodli tuto kategorii vyloučit. Celkem bylo tedy vyhodnoceno 40 gymnastek a 52 studentek.
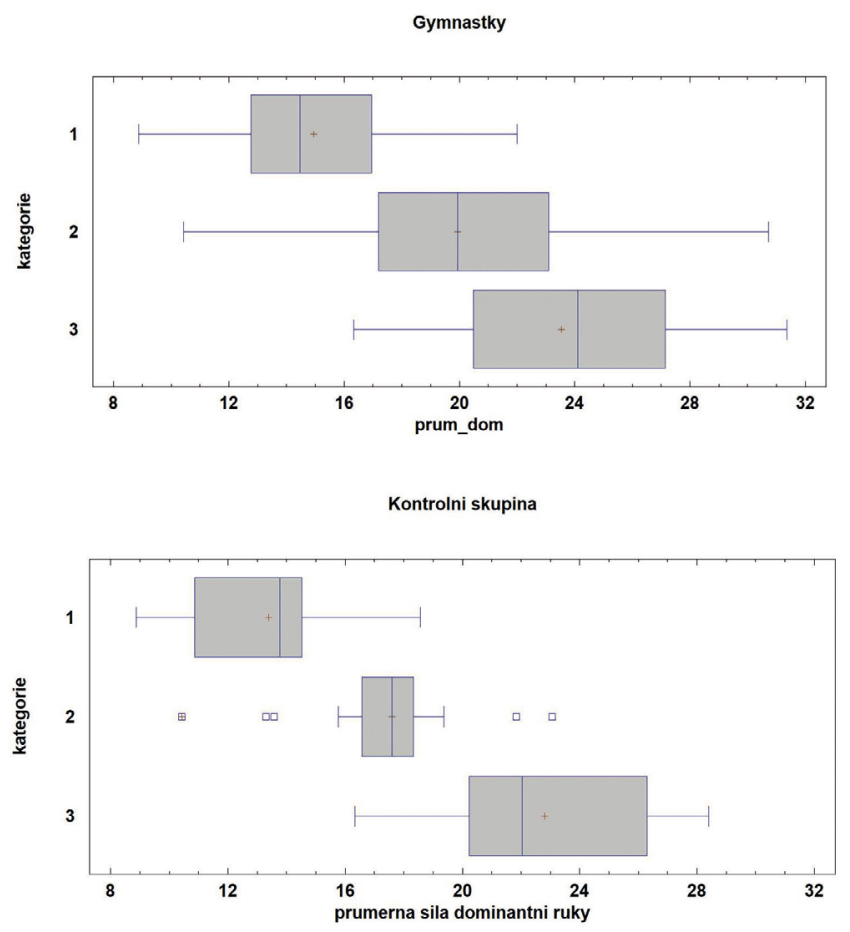

Graf 1: Krabicový graf průměrné síly dominantní ruky u gymnastek a kontrolní skupiny studentek.

\section{Instrumentář a měřené hodnoty}

K vyšetřování byl využit standardní antropometrický instrumentár: antropometr GPM, pásová míra, osobní digitální váha Tanita BC-545. K měření síly stisku byl využit elektromechanický dynamometr Chatillon DFF II (Ametek 2015) vybavený příslušenstvím umožňujícím individuální nastavení rozpětí př̀i měření síly stisku ruky. To zaručuje minimalizaci chyby, která vzniká př̀i neodpovídajícím nastavení měřidla. Adaptér byl vytvořen na základě návrhu pracovníků Ústavu antropologie metodou 3D tisku. Zjištěné hodnoty síly byly zaznamenávány $\mathrm{v}$ jednotkách kgf, s přesností na jednu desetinu. Při měření tělesné výšky bylo měřeno $\mathrm{v}$ jednotkách $\mathrm{cm}, \mathrm{s}$ přesností na jednu desetinu. Hmotnost byla měřena v jednotkách kg, s přesností na jednu desetinu. Stejně tak obvody prredloktí byly měřeny $s$ přesností na desetinu centimetru.

\section{Postup}

Podmínkou pro účast na antropologickém vyšetření a vyšetření síly stisku bylo odevzdání informovaného souhlasu, po- 


\begin{tabular}{|l|c|l|l|l|l|l|c|}
\hline kategorie & počet & $\begin{array}{l}\text { věkový } \\
\text { rozsah } \\
\text { (let) }\end{array}$ & $\begin{array}{l}\text { průměrná } \\
\text { hmotnost }(\mathrm{kg})\end{array}$ & $\begin{array}{l}\text { průměrná } \\
\text { tělesná výška } \\
(\mathrm{cm})\end{array}$ & $\begin{array}{l}\text { průměrné } \\
\text { BMI }\end{array}$ & $\begin{array}{l}\text { průměrná síla stisku } \\
\text { dominantní ruky } \\
\text { (kgf) }\end{array}$ & $\begin{array}{l}\text { průměrná síla } \\
\text { stisku nedomi- } \\
\text { nantní ruky (kgf) }\end{array}$ \\
\hline I. & 14 & $7-9$ & $29.02(4.45)$ & $133.44(5.26)$ & $16.22(1.5)$ & $17.32(2.84)$ & $16.16(2.87)$ \\
\hline II. & 21 & $10-11$ & $35.70(5.59)$ & $144.79(7.5)$ & $16.91(1.27)$ & $21.92(3.46)$ & $21.01(3.46)$ \\
\hline III. & 5 & $12-13$ & $43.62(6.65)$ & $153.44(5.35)$ & $18.47(2.08)$ & $25.72(4.64)$ & $24.53(4.25)$ \\
\hline IV. & 2 & $14-15$ & $45.40(0.99)$ & $153.80(4.1)$ & $19.22(1.44)$ & $24.70(6.22)$ & $23.45(7.5)$ \\
\hline
\end{tabular}

Tab. 1. Popisná statistika sportovních gymnastek dle věkových kategorií. V závorce uvedena směrodatná odchylka (SD).

\begin{tabular}{|l|c|c|c|c|l|l|c|}
\hline kategorie & počet & $\begin{array}{l}\text { věkový } \\
\text { rozsah } \\
(\text { let })\end{array}$ & $\begin{array}{l}\text { průměrná } \\
\text { hmotnost }(\mathrm{kg})\end{array}$ & $\begin{array}{l}\text { průměrná } \\
\text { tělesná výška } \\
(\mathrm{cm})\end{array}$ & $\begin{array}{l}\text { průměrné } \\
\text { BMI }\end{array}$ & $\begin{array}{l}\text { průměrná síla stisku } \\
\text { dominantní ruky } \\
\text { (kgf) }\end{array}$ & $\begin{array}{l}\text { průměrná síla } \\
\text { stisku nedomi- } \\
\text { nantní ruky (kgf) }\end{array}$ \\
\hline I. & 22 & $7-9$ & $30.53(6.98)$ & $133.42(6.78)$ & $16.99(2.84)$ & $13.42(2.52)$ & $12.62(2.22)$ \\
\hline II. & 15 & $10-11$ & $40.21(10.92)$ & $147.98(5.05)$ & $18.27(4.42)$ & $17.18(3.17)$ & $15.12(3.42)$ \\
\hline III. & 15 & $12-13$ & $49.76(6.15)$ & $159.69(4.76)$ & $19.54(2.56)$ & $22.80(4.15)$ & $20.62(4.83)$ \\
\hline IV. & 16 & $14-15$ & $54.31(0.7)$ & $166.24(2.9)$ & $19.59(2.79)$ & $25.21(4.4)$ & $24.29(4.16)$ \\
\hline
\end{tabular}

Tab. 2. Popisná statistika studentek dle věkových kategorií. V závorce uvedena směrodatná odchylka (SD).

depsaného rodiči (nebo zákonnými zástupci). Před měřením byla každá probandka seznámena s průběhem měření. Všechny gymnastky absolvovaly měření v gymnastických trikotech, které měření nepřekážely a měly zanedbatelnou hmotnost. Všechny studentky absolvovaly měření v zanedbatelném oblečení. Měřena byla tělesná výška a hmotnost a obvod předloktí (dle standardní metodiky). Dále byla měřena síla stisku ruky. Probandka byla v pozici aktivně vzpř́ímeného sedu na židli u stolu, obě nohy položené na podlaze, ramena narovnaná a horní končetiny ohnuty v loktech v úhlu $90^{\circ}$. Dynamometr byl upevněn na desce stolu, úchopová madla dynamometru byla přizpůsobena konkrétní velikosti ruky probandky. Předloktí ani loket se neopíraly o desku stolu. Probandky byly instruovány, aby maximální silou stiskly madla př́istroje tak, aby maximální síly dosáhly během cca 3 sekund. Střídavě byla měřena síla stisku pravé i levé ruky (s cca minutovými intervaly mezi měřeními na regeneraci), tři opakování každou rukou. Měření probíhalo unifikovaně u gymnastek i studentek. Získaná data byla vyhodnocena v prostředí Excel, statistického programu $\mathrm{R}$ a Statgraphics 18 . V rámci čištění dat byly vyřazeny tř̌i studentky na základě dotazníkového šetření, kde uvedly, že se věnují silovému sportu, např. horolezectví. Data byla přepsána do excelové tabulky, odkud byla aplikována $\mathrm{v}$ prostředí $\mathrm{R}$ pro vytvoření přehledových tabulek (viz kapitola Výsledky). Dále byla data transformována kvůli šikmosti a špičatosti v programu excel. Následně byla data vložena do programu Statgraphics 18, kde byla provedena Two Sample Comparison analýza, t-test, dále polynomická regrese (R-squared (adjusted for d.f.)) a lineární nezávislost obvodu předloktí a síly stisku ruky. Porovnání síly stisku ruky bylo rozděleno na dominantní a nedominantní ruku, k zohlednění laterality horních končetin jednotlivých účastnic.

\section{VÝSLEDKY}

V rámci výsledků byly vypracovány tabulky s deskriptivní statistikou pro gymnastky a studentky v jednotlivých věkových kategoriích (viz tab. 1 a 2).

V rámci I., II. a III. kategorie byla testována shoda souboru gymnastek s kontrolním souborem studentek u průměrné síly stisku ruky na dominantní i nedominantní končetině, BMI, tělesná výška i hmotnost, společně s BMI (Body Mass Index). $\mathrm{V}$ rámci celého souboru byla testována souvislost mezi obvodem předloktí a silou dané končetiny.

V první kategorii pomocí t-testu nebyl zamítnut rozdíl mezi silou stisku dominantní ruky (P-value $=0,00016207)$ i nedominantní ruky (P-value $=0,000275647)$. T testem ovšem byl zamítnut rozdíl v tělesné výšce (P-value $=0,965613)$, hmotnosti $(\mathrm{P}$-value $=0,724846)$ i BMI (P-value $=0,543113)$. Rozdíl mezi mezi obvody předloktí ve vztahu $\mathrm{k}$ př́slušnosti ke skupině nebyl nalezen $\mathrm{v}$ prrípadě dominantní ani nedominantní ruky $(\mathrm{P}$-value $=0,530845, \mathrm{P}$-value $=0,583624)$. Polynomickou regresí lze vysvětit příslušností ke skupině (gymnastky, studentky) 32,6599\% variability u průměru dominantní ruky, u průměru nedominantní ruky pak $30,6269 \%$, v obou případech se jedná o polynom 1 . stupně $(\mathrm{P}$-value $=0,0002$, $\mathrm{P}$-value $=0,0003$ ).

Ve druhé kategorii pomocí t-testu nebyl zamítnut rozdíl mezi skupinou gymnastek a kontrolní skupinou v síle stisku dominatní ruky (P-value $=0,000178033)$ ani nedominantní ruky $(\mathrm{P}$-value $=0,0000029551)$. Rozdíl $\mathrm{v}$ tělesných výškách ani hmotnostech či BMI nebyl nalezen (P-value $=0,17858$, $\mathrm{P}$-value $=0,167615, \mathrm{P}$-value $=0,538691)$. Rozdíl mezi obvody předloktí a prríslušností ke skupině nebyl nalezena $\mathrm{v}$ případě dominantní ani nedominantní ruky (P-value $=0,255707$, 
P-value $=0,300781)$. Polynomickou regresí lze vysvětlit příslušností ke skupině (gymnastky nebo studentky) 32,3041 \% variability u průměru dominantní ruky. $U$ průměru nedominantní ruky př́slušností ke skupině vysvětlíme 46,3409\% variability. (P-value $=0,0002, \mathrm{P}$-value $<0,0001) \mathrm{V}$ obou prrípadech se jedná o polynom 1 . stupně.

Ve třetí kategorii byl pomocí t-testu zamítnut rozdíl mezi skupinou gymnastek a kontrolní skupinou, v síle stisku dominantní i nedominantní ruky (P-value $=0,195804$, $\mathrm{P}$-value $=$ 0,120388). Rozdíl mezi skupinami v tělesné výšce a hmotnosti nebyl zamítnut (P-value $=0,0236571, \mathrm{P}$-value $=0,0480046)$, u BMI byl rozdíl zamítnut $(\mathrm{P}$-value $=0,380844)$. Rozdíl mezi obvody předloktí a př́slušností ke skupině nebyl nalezen $\mathrm{v}$ případě dominantní ani nedominantní ruky (P-value = 0,829141, P-value $=0,527836$ ). Polynomickou regresí nelze vysvětlit př́slušností ke skupině variabilitu u dominantní ani nedominantní ruky $(\mathrm{P}$-value $=0,1958, \mathrm{P}$-value $=0,1204)$.

\section{Obvod předloktí a síla}

$\mathrm{V}$ rámci této analýzy nebylo přihlíženo $\mathrm{k}$ věku, ale pouze ke skupině, proto jsme mohli využít všechna data. Ve skupině gymnastek $(n=42)$ byla jednoduchou regresí nalezena závislost obvodu předloktí na síle stisku dané ruky. U dominantní ruky můžeme touto regresí vysvětlit 53,8189\% variability (R-squared (adjusted for d .f.)), u nedominantní ruky pak 46,9697\%, obě P-value < 0,0001. Korelační koeficient 0,741251 . V kontrolní skupině $(\mathrm{n}=71)$ pak byla jednoduchou regresí nalezena závislost obvodu předloktí na síle stisku dané ruky. U dominantní ruky můžeme touto regresí vysvětlit 43,6119\% variability (R-squared (adjusted for d.f.), u nedominantní ruky pak 36,1384\%, obě P-value $<0,0001$. Korelační koeficient 0,608693 .

\section{DISKUSE}

Měření síly stisku patří mezi základní vyšetření, která mají výpovědní hodnotu o fyzické kondici sportovce. Náš předpoklad, že faktorem velikosti síly stisku ruky můžeme skupinu sportovních gymnastek oddělit od běžné populace stejného věku nebyl zamítnut ve dvou kategoriích. Tento předpoklad byl postaven na obsahu sportovní gymnastiky a vlivu tréninků. Ve věku počátku školní docházky (odpovídající počátku I. kategorie) dochází ke zpřesňování jemné motoriky a koordinaci úchopů, což společně se zvýšenou zátěží může vést k vyšší síle stisku u gymnastek. Zvláště vývojová fáze, odpovídající I. a částečně II. kategorii, je charakterizována pomalým růstem $\mathrm{a}, \mathrm{v}$ kombinaci s náročným gymnastickým tréninkem, nárůstem podílu svalové hmoty. Naopak v období III. kategorie, kdy bychom kvůli růstovému spurtu očekávali navýšení silových schopností, nenacházíme významný rozdíl mezi výkony gymnastek a studentek. V období růstového spurtu dochází k poklesu svalového tonu a snižuje se také podíl svalové hmoty na celkové složení těla (Javorka et al. 1996; Malá - Klementa 1985). Ovšem toto odchýlení od výsledku předchozích dvou skupin můžeme také přičítat nízkému počtu sportovních gymnastek ve III. kategorii. Lze pouze předpokládat. že bychom obdobné údaje jako v prvních dvou kategoriích získali i u dívek mezi 14-17 lety, kdy se udává ve sportovní gymnastice žen výkonnostní vrchol (Dovalil - Choutka 2002a) a je již završeno období růstového spurtu u dívek (Dylevský 2017). Tento předpoklad je ovšem zapotřebí ověřit dalším výzkumem. Alespoň tedy v prvních dvou kategoriích nebyl náš předpoklad zamítnut a my můžeme usuzovat, že sportovní gymnastky vzhledem $\mathrm{k}$ populaci disponují větší svalovou silou předloktí.

V rámci dalších analýz byl sledován vztah síly stisku ruky a maximálního obvodu předloktí. $\mathrm{V}$ tomto prípadě byla v obou skupinách nalezena silná korelace. Jednoduchá regrese nám v př́padě gymnastek dále potvrdila, že sílou stisku ruky můžeme vysvětlit cca $50 \%$ variability maximálního obvodu předloktí. Ovšem u studentek je takto možno vysvětlit pouze okolo $40 \%$. Tento faktor tedy není dobrým ukazatelem. Maximální obvod předloktí nepostihuje dostatečně stav síly.

Tento oddíl byl doplněn o předpoklad odlišnosti v tělesné výšce mezi sportovními gymnastkami a stejnou věkovou skupinou $\mathrm{v}$ populaci. V prvních dvou kategoriích jsme rozdíl nenalezli, což si můžeme vysvětlovat tím, že věkové rozpětí těchto dvou kategorií odpovídá období mladšího školního věku, charakteristického zpomalením růstu (Malá - Klementa 1985). V tomto období se organismus připravuje na pubertální spurt a vyvíjí se kosterní i svalová soustava. K opravdové specializaci a přechodu na těžší prvky, zvýhodňující menší postavu dochází později. U třetí kategorie nebyl zamítnut předpoklad o nižší tělesné výšce a hmotnosti sportovních gymnastek, ne však v BMI. Tento výsledek si můžeme vysvětlovat růstovým spurtem, který se u gymnastek může projevit v menší míře či opožděně. Na tomto jevu může mít svůj podíl také familiární komponenta (Baxte-Jones 2013; Malá - Klementa 1985; Rogol - Clarc - Roemmich 2000). Velmi významným faktorem. který přispívá $\mathrm{k}$ výškové odlišnosti gymnastek, bývá selekce dívek, které mají predikovánu menší tělesnou výšku v dospělosti. Tato selekce probíhá většinou uměle trenéry (Baxte-Jones 2013). Může dojít v tomto směru i k nezáměrné selekci, kdy dívky vyššího vzrůstu nemají takovou motivaci k pokračování v tomto sportu $\mathrm{z}$ důvodu obtížnějšího provádění technicky náročných prvků, u kterých je menší tělesná výška výhodou.

\section{ZÁVĚR}

Naším hlavním závěrem je konstatování odlišností sportovních gymnastek od stejně staré běžné populace. Můžeme konstatovat, že v mladších věkových kategoriích byl předpoklad silových odlišností sportovních gymnastek správný. Naopak $\mathrm{v}$ těchto kategoriích nenacházíme rozdíly v tělesné výšce, hmotnosti nebo BMI. Rozdíl v BMI nebyl nalezen ani ve III. věkové kategorii, kde byl naopak nalezen rozdíl v tělesné výšce a hmotnosti. V této kategorii ovšem nebyl zaznamenán rozdíl $\mathrm{v}$ síle stisku ruky mezi sportovními gymnastkami a stejnou věkovou skupinou v populaci. Důvodem pro to může být nedostatečný 
počet sportovních gymnastek. Tento poznatek vybízí k zaměření se v budoucnu právě na tuto i starší věkové kategorie.

Celkově je metodika výzkumu využitelná i v budoucnu pro obdobné výzkumy. Díky užití elektromechanického dynamometru Chatillon DFF II., doplněného o konstrukci vyrobené na 3D tiskárně a jeho ukotvení na pevném stole, bylo i pro mladší probandy bezproblémové provést stanovené měření. Tento způsob měření je tedy vhodný i pro měření mladších sportovců.

\section{PODĚKOVÁNÍ}

Velké poděkování patří účastnicím výzkumu z řad žaček a studentek obou základních škol a gymnázia, za pomoc s realizací měření jejich zaměstnancům, jmenovitě pak panu Mgr. Petru Novákovi, paní Mgr. Jaroslavě Kasákové, panu RNDr. Milanu Dundrovi, CSc. a panu Mgr. Michalu Šturmovi. Velké díky patři také gymnastkám, vedení a trenérům zúčastněných gymnastických oddílů. Jmenovitě slečně Dominice Lisé, paní Lence Barešové a paní Mgr. Ivaně Kř́ístelové.

\section{LITERATURA}

Ametek sensors, tests and calibration (2015): DFE II Series Digital Force Gauges (online). https://www.ametektest.com/products/force-gauges/digital-force-gauges/dfe-ii-series.
Baxte-Jones, Adam D.G. (2013): Growth. maturation and training. In: Caine, Dennis - Russel, Keith. Lim, Liesbeth, eds., Gymnastics. International Olympic Committee. John Willey and Sons Ltd.

Dovalil, Josef - Choutka, Miroslav (2002): Sportovní výkon a jeho struktura jako východisko racionálního tréninku. In: Dovalil, Josef - Choutka, Miroslav a kolektiv, eds. Výkon a trénink ve sportu. Olympia.

Dovalil, Josef (2002): Kondiční příprava. Dlouhodobá koncepce sportovního tréninku. Tréninkové cykly. In: Dovalil, Josef - Choutka, Miroslav a kolektiv, eds. Výkon a trénink ve sportu. Olympia.

Dylevský, Ivan (2017): Anatomie dítěte. Nipioanatomie, 2. díl. Praha: České vysoké učení technické.

Hedbávný, Petr - Cacek, Jan - Svobodová, Lenka (2014): Anthropometric characteristics in Czech elite female gymnasts. Journal of Human Sport and Exercise, 9(1). DOI: 10.14198/jhse.2014.9.Proc1.36

Javorka, Kamil a kolektiv (1996): Klinická fyziologia pre pediatrov. Žilina: Osveta.

Krištofič, Jaroslav (2006): Pohybová př́prava pro děti: Koordinační a kondični gymnastická cvičení. Praha: Grada Publishing.

Krištofič, Jaroslav (2009): Technika pohybových činností v gymnastických sportech. Teoretické základy gymnastických aktivit. Pohybové učení v gymnastice. In: Krištofič, Jaroslav a kolektiv. Gymnastika. Praha: Nakladatelství Karolinum.

Malá, Helena - Klementa, Josef (1985): Biologie dětí a dorostu. Praha: SPN.

Riegerová, Jarmila - Valenta, Michal - Ulbrichová, Marie (2006): Morfologicko-funkční vztahy. In: Riegerová, Jarmila - Přidalová, Miroslava - Ulbrichová, Marie. Marie, eds. Aplikace fyzické antropologie v tělesné výchově a sportu (příručka funkční antropologie). Olomouc: Hanex.

Rogol, Alan D. - Clarc, Pamela A. - Roemmich, James (2000): Growth and pubertal development in children and adolescents: effects of diet and physical activity. American Journal of Clinical Nutrition. 72(2). DOI 10.1093/ajcn/72.2.521S

Skopová, Marie - Zítko, Miroslav (2013): Základní gymnastika. Praha: Nakladatelství Karolinum. 
